\title{
KOMUNIKASI NON VERBAL (MAKNA KINESIK) PESULAP DALAM PERTUNJUKAN SULAP KLASIK
}

\author{
Intan Putri*
}

\begin{abstract}
Magic games continue to evolve along with advances in science and technology. However, classic magic remains present at every modern magic show. In this study researchers focused more on the kinesic message than non-verbal messages. This is because in classic magic shows, it is more dominant to use kinesik in delivering messages to the audience. Classic magic shows are magic shows that lack dialogue and require deep interpretation by magicians. The purpose of this study was to determine the meaning of magician kinesik in classical magic shows. This research is a qualitative descriptive study. Determination of informants is done by purposive sampling. Where the informant is chosen deliberately based on the criteria that have been determined and determined based on the research objectives. In this study the primary informant was Ray Antylogic and this study used in-depth interviews, participant observation and documentation. The results of the study showed that the success of classical magic shows was determined by the message kinesik in every classic magic game from the beginning of the game until the end was accepted or understood by the audience. The kinesik message that the magician wants to convey has been accepted or understood or conveyed to the audience. There are things in the kinesik message especially the facial messages that only occur naturally or spontaneously.
\end{abstract}

Keywords : Communication, Kinestic, Classic Magic

\section{PENDAHULUAN}

Perkembangan ilmu pengetahuan dan teknologi yang terjadi saat ini tidak hanya berdampak pada perkembangan ekonomi, politik, sosial ataupun budaya. Perkembangan ilmu pengetahuan dan teknologi juga berdampak pada perkembangan dunia hiburan. Dunia hiburan terutama seni pertunjukan yang menarik minat masyarakat, salah satu seni pertunjukan tersebut adalah sulap. Sulap merupakan seni pertunjukan yang menampilkan gabungan dari berbagai seni yang ada seperti seni rupa, tari, musik dan lain-lain. Dalam sulap juga memakai gabungan dari berbagai ilmu (Interdisipliner) seperti ilmu kimia, fisika, biologi, psikologi, komunikasi dan lainlain. Sulap menampilkan kecepatan atau kelihaian tangan pesulap, manipulasi, efek reaksi kimia ataupun hasil kerja teknologi dan perlengkapan serta peralatan pesulap yang biasa kita kenal dengan trik-trik sulap.

Perkembangan sulap dalam seni pertunjukan pada saat ini tidak lepas dari sejarah perkembangan sulap itu sendiri.

*Penulis adalah Dosen Jurusan Dakwah IAIN Bengkulu 
Sebuah Papirus peninggalan Mesir Kuno yang menceritakan pertunjukan sulap untuk menghibur Fir'aun Cheops. Papirus ini menjadi catatan tertua yang berkenaan dengan sulap sehingga disinyalir permainan sulap berasal dari Mesir Kuno sekitar 2700 SM. Cups and Balls (cangkir dan bola) adalah salah satu trik sulap tertua. Hal ini dapat dilihat pada dinding kuburan Beni Hasan yang berasal dari tahun 2500-2200 SM. Hingga sampai tahun 1750-an sulap Modern mulai berkembang, sulap modern menggabungkan ilusi teknologi dan kecepatan tangan. Pada tahun 1845, Jean Eugene Robert-Houdin menampilkan ilusi bertema Eternal Suspension (Trik mengambang di udara) dan berkat itu Robert-Houdin dikenal sebagai Bapak Sulap Modern.

Permainan sulap terus berkembang beriringan dengan kemajuan ilmu pengetahuan dan teknologi. Hingga saat ini berbagai jenis ataupun aliran sulap terus menambah warna dalam seni pertunjukan sulap. Namun, sulap klasik tetap hadir di setiap pertunjukan sulap modern saat ini. Dalam pertunjukan sulap terutama sulap klasik, pesulap melakukan komunikasi melalui permainan sulapnya. Keberhasilan dari pertunjukan sulap adalah bagaimana pesulap dapat berkomunikasi melalui permainan sulapnya dan dapat diterima oleh penonton.

Komunikasi adalah suatu proses dimana dua orang atau lebih membentuk atau melakukan pertukaran informasi dengan satu sama lainnya, yang pada gilirannya akan tiba pada saling pengertian yang mendalam. Dalam hal ini lebih menspesifikan hakikat dari sebuah hubungan dengan adanya suatu pertukaran informasi atau pesan. Adanya pertukaran pesan tersebut terjadilah perubahan sikap dan tingkah laku ataupun secara bersamaan dapat tercipta saling pengertian antara komunikator dan komunikan.Dalam pertunjukan sulap yang bertindak sebagai komunikator adalah pesulap dan penonton sebagai komunikan. Interpretasi pesan non verbal seperti gerak tubuh, ekspersi wajah, kualitas vokal dan isyarat non verbal tidak dapat dibuat-buat atau direkayasa agar tampak asli bagi yang bukan ahlinya dalam bidang ini. Tanpa disadari komunikasi non verbal dapat menjadi alat komunikasi untuk mengungkapkan kebenaran dari komunikasi verbal. Komunikasi non verbal dapat mengungkapkan hal-hal seperti emosi yang tidak dapat ditafsirkan melalui komunikasi verbal.

Seorang pesulap dalam melakukan pertunjukan sulap memiliki script atau naskah yang harus dilatih secara rutin dan berulang-ulang. Hal ini dikarenakan 
Syi'ar Vol. 18 No. 1 Januari-Juni 2018

seorang pesulap harus dapat menyampaikan pesan kepada penonton dalam pertunjukan sulap melalui permainan sulapnya. Permainan sulap sendiri berisi rangkaian pesan non verbal. Apabila tidak berlatih secara rutin dan berulang-ulang maka dapat memunculkan gerakan-gerakan diluar script atau naskah sehingga pesan non verbal tersebut tidak dapat tersampaikan dengan baik dan dapat menciptakan kegagalan dalam pertunjukan sulap.Dalam penelitian ini peneliti lebih memfokuskan pada pesan kinesik dari pesan non verbal. Hal ini dikarenakan dalam pertunjukan sulap klasik lebih dominan memakai kinesik dalam penyampaian pesan kepada penonton.

Pertunjukan sulap klasik merupakan pertunjukan sulap yang minim dialog dan membutuhkan interpretasi yang mendalam terhadap gerakan-gerakan tubuh yang ditampilkan oleh pesulap. Sulap klasik adalah permainan yang mengutamakan bahasa tubuh (kinesik) dalam setiap pertunjukannya. Hal tersebut dikarenakan bahasa tubuh atau kinesik dalam pertunjukan sulap bentuk komunikasi ataupun interaksi yang dilakukan antara pesulap dan penonton, permainan sulap sendiri adalah media untuk pesulap menyampaikan pesannya kepada penonton.

Seorang pesulap merangkai atau menyampaikan pesan kinesik kepada penonton saat pertunjukan sulap klasik. Keberhasilan pertunjukan sulap itu sendiri ditentukan apakah pesan kinesik yang ada dalam setiap permainan sulap klasik dari awal permainan hingga akhir dapat diterima atau dimengerti ataupun sampai pada penonton. Dengan adanya penelitian ini dapat menjelaskan makna kinesik pesulap dalam pertunjukan sulap klasik, yang pada mulanya pertunjukan sulap hanya dijadikan hiburan semata namun tanpa disadari bahwa dalam permainan sulap berisi makna-makna kinesik yang dapat dijelaskan secara keilmuan. Selain itu, penelitian ini dapat membantu pesulap memperkaya variasi dalam penyampaian pesan-pesan kinesik tersebut agar lebih mudah dimengerti dan dipahami sehingga tingkat tersampainya dan keberhasilan pertunjukan sulap semakin besar.

\section{KAJIAN TEORI}

Komunikasiadalah proses penyampaian pesan dari komunikator kepada komunikan dengan atau melalui media. Komunikasi adalah hal yang paling mendasar dari segala interaksi, baik antar individu dengan individu, individu dengan kelompok ataupun kelompok dengan kelompok. Seperti yang diungkapkan oleh Shannon dan Weaver (1949) bahwa komunikasi adalah bentuk interaksi manusia yang saling mempengaruhi satu sama lainnya, sengaja atau tidak sengaja. Tidak terbatas pada bentuk komunikasi 
menggunakan bahasa verbal, tetapi juga dalam hal ekspresi muka, lukisan, seni dan teknologi ${ }^{\mathrm{i}}$.

"Menurut studi Mahrabian (1971), Sebelum bahasa verbal digunakan dalam komunikasi, manusia menggunakan bahasa tubuh atau bahasa non verbal sebagai alat komunikasi. Dapat dikatakan bahwa komunikasi non verbal lebih dahulu dipergunakan dalam kehidupan sehari-hari sebelum adanya komunikasi verbal. Namun, pada saat ini komunikasi non verbal tetap digunakan. Tingkat kepercayaan dari pembicaraan orang hanya 7 persen berasal dari bahasa verbal, 38 persen dari vokal suara dan 55 persen dari ekspresi muka ${ }^{\mathrm{ii}}$,

\section{Komunikasi non verbal adalah} komunikasi yang menggunakan pesan non verbal. Istilah non verbal biasanya digunakan untuk menggambarkan peristiwa komunikasi selain kata-kata yang terucap dan tertulis. Secara teoritis, komunikasi verbal dan komunikasi non verbal dapat dipisahkan. Namun dalam kenyataannya, kedua jenis komunikasi ini saling jalin menjalin, saling melengkapi dalam komunikasi yang dilakukan seharihari. Pesan komunikasi non verbal merupakan penegasan, pelengkap ataupun pengganti dari pesan komunikasi verbal dapat berupa gerakan, body language ataupun isyarat yang telah disepakati oleh komunikator dan komunikan. Menurut Knapp terdapat lima fungsi pesan non verbal ${ }^{\text {iii }}$ yaitu:

\section{Repetisi}

Mengulang kembali gagasan yang sudah disajikan secara verbal.

\section{Subtitusi}

Menggantikan lambang-lambang verbal.

\section{Kontradiksi}

Menolak pesan verbal atau memberikan makna yang lain terhadap pesan verbal.

\section{Komplemen}

Melengkapi atau memperkaya makna pesan non verbal.

\section{Aksentuasi}

Menegaskan pesan verbal atau menggaris bawahinya.

$$
\begin{aligned}
& \text { "Menurut Leather (1976), Pesan non } \\
& \text { verbal pada tiga kelompok besar } \\
& \text { yaitu pesan non verbal visual yang } \\
& \text { meliputi kinesik, prosemik dan } \\
& \text { artifaktual, pesan non verbal auditif } \\
& \text { meliputi paralinguistik dan pesan } \\
& \text { non verbal non auditif meliputi } \\
& \text { penciuman dan sentuhan iv". }
\end{aligned}
$$

Pesan komunikasi non verbal memiliki kode non verbal. Kode non verbal adalah sejumlah perilaku yang digunakan untuk menyampaikan makna.Kode non verbal dikenal juga dengan bahasa isyarat atau bahasa diam (silent language). Pemberian makna atau arti dalam sebuah kode non verbal berbeda-beda dalam setiap budaya. 
"Dari berbagai studi yang pernah dilakukan sebelumnya, kode non verbal dapat dikelompokan dalam beberapa bentuk, antara lain: kinesics (gerakan badan), gerakan mata, sentuhan, paralanguage (irama suara), diam, postur tubuh, kedekatan dan ruang, warna, waktu, bunyi dan bau" $"$

Pesan kinesik merupakan pesan non verbal yang ditunjukan seseorang dengan isyarat tubuh atau gerakan badan. Kinesik adalah gerakan-gerakan tubuh atau badan berupa gerakan dari sebagian atau seluruh tubuh maupun benda-benda yang digerakkan pelaku komunikasi.Pesan kinesik adalah pesan non verbal yang menggunakan gerakan tubuh yang berarti, terdiri dari tiga komponen utama ${ }^{\mathrm{vi}}$ :

1. Pesan Fasial

Menggunakan air muka untuk menyampaikan makna tertentu. Berbagai penelitian menunjukkan bahwa wajah dapat menyampaikan paling sedikit sepuluh kelompok makna: kebagiaan, rasa terkejut, ketakutan, kemarahan, kesedihan, kemuakan, pengecaman, minat, ketakjuban, dan tekad. Menurut Birdwhistell, perubahan yang sangat sedikit saja dalam area wajah dapat menciptakan perbedaan yang sangat besar.

Leathers (1976) menyimpulkan penelitian-penelitian tentang wajah sebagai berikut: a. Wajah mengkomunikasikan penilaian dengan ekspresi senang dan tak senang, yang menunjukkan apakah komunikator memandang objek penelitiannya baik atau buruk.

b. Wajah mengkomunikasikan berminat atau tak berminat pada orang lain atau lingkungan.

c. Wajah mengkomunikasikan intensitas keterlibatan dalam suatu situasi.

d. Wajah mengkomunikasikan tingkat pengendalian individu terhadap pernyataan sendiri dan wajah barangkali mengkomunikasikan adanya atau kurang pengertian ${ }^{\text {vii }}$.

Selain wajah, kontak mata adalah yang paling ekspresif dalam komunikasi. Kontak mata mempunyai dua fungsi dalam komunikasi ${ }^{\text {viii }}$ yaitu :

a. Sebagai fungsi pengatur adalah kontak mata memberitahukan orang lain apakah adanya ketertarikan atau menghindar.

b. Sebagai ekspresif adalah memberitahukan perasaan kepada orang lain. Mata adalah alat komunikasi berarti dalam memberikan isyarat, yang mana setiap gerakan-gerakan mata memiliki arti tersendiri ${ }^{8}$.

\section{Pesan Gestural}

Menunjukkan gerakan sebagian anggota badan seperti gerakan tangan untuk mengkomunikasi berbagai makna. Meski 
gerakan tangan yang digunakan sama namun makna yang terkandung berbeda.Menurut Galloway ${ }^{\text {ix }}$ pesan gestural digunakan untuk mengungkapkan

a. Mendorong atau membatasi.

b. Menyesuaikan atau mempertentangkan.

c. Responsif atau tidak responsif.

d. Perasaan positif atau negatif.

e. Memperhatikan atau tidak memperhatikan.

f. Melancarkan atau tidak reseptif.

g. Menyetujui atau menolak.

\section{Pesan Postural}

Berkenaan dengan keseluruhan anggota badan, Mehrabian ${ }^{\mathrm{x}}$ menyebutkan tiga makna yang dapat disampaikan dalam pesan postural, yaitu :

\section{a. Immediacy}

Ungkapan kesukaan dan ketidak sukaan terhadap individu yang lain. Postur yang condong ke arah yang diajak bicara menunjukkan kesukaan dan penilaian positif.

\section{b. Power}

Mengungkapkan status yang tinggi pada diri komunikator. Anda dapat membayangkan postur orang yang tinggi hati di depan anda, dan postur orang yang merendah.

c. Responsiveness

Individu dapat bereaksi secara emosional pada lingkungan secara positif dan negatif. Bila postur anda tidak berubah, anda mengungkapkan sikap yang tidak responsif ${ }^{10}$.

Postur tubuh dapat mempengaruhi citra diri yang dimiliki seseorang. Gambaran tentang diri seseorang memegang peranan penting dalam komunikasi.Dalam pertunjukan sulap terutama sulap klasik, seorang pesulap melakukan komunikasi melalui permainan sulapnya. Pertunjukan sulap klasik merupakan pertunjukan sulap yang minim dialog dan membutuhkan interpretasi yang mendalam terhadap gerakan-gerakan tubuh yang ditampilkan oleh pesulap. Dalam pertunjukan sulap ini komunikasi yang dilakukan adalah komunikasi non verbal. Berhasilnya komunikasi non verbal yang dilakukan seorang pesulap dalam pertunjukan sulap itu sendiri ditentukan apakah pesan non verbal yang ada dalam setiap permainan sulap klasik dari awal permainan hingga akhir dapat diterima atau dimengerti ataupun sampai pada penonton.

"Menurut Jatmika dan Jibran, Sulap adalah sebuah pemainan yang menggunakan kelihaian tangan, memanipulasi hasil kerja dari perlengkapan ataupun peralatan tertentu. Metode yang dipakai adalah manipulasi audio-visual dan alat bantu. Tidak hanya itu, dalam sulap pun berlaku adanya pengalih 
perhatian, sugesti, duplikat dan penyembunyian ${ }^{\mathrm{xi}}$.

Sulap merupakan seni pertunjukan yang menampilkan gabungan dari berbagai seni yang ada seperti seni rupa, tari, musik, dan lain-lain. Dalam sulap juga memakai gabungan dari berbagai ilmu (Interdisipliner) seperti ilmu kimia, fisika, biologi, psikologi, komunikasi dan lainlain. Sulap menampilkan kecepatan atau kelihaian tangan pesulap, manipulasi, efek reaksi kimia, ataupun hasil kerja teknologi dan perlengkapan serta peralatan pesulap yang biasa kita kenal dengan trik-trik sulap. Sulap adalah sebuah seni komunikasi, ide dan gerak yang dijadikan satu secara rutin yang hasilnya tidak dapat Anda pikirkan sebelumnya dan jangan jadikan sulap hanya sebuah trik saja, tapi jadikan sebuah keajaiban. Sulap atau lebih dikenal dengan magic berasal dari bahasa Latin yaitu Majus yang berarti orang bijak atau raja-raja dari timur.

\section{Metode Penelitian}

Penelitian ini merupakan penelitian deskriptif kualitatif karena untuk mengetahui makna kinesik pesulap dalam pertunjukan sulap klasik maka diperlukan teknik pengumpulan data dengan observasi partisipan dengan melakukan pengamatan secara langsung dan berpartisipasi dalam kegiatan informan, wawancara mendalam yang bersifat terbuka dan dokumentasi baik untuk mendapatkan data primer ataupun untuk mencari data sekunder.Dalam penelitian ini, peneliti menentukan informan dengan carapurposive sampling dan yang menjadi informan primer dalam penelitian peneliti adalah Ray Antylogic. Hal ini dengan pertimbangan Ray Antylogic merupakan salah satu pencetus berdirinya Three Logic Academy and Community (3Logic) pada tahun 2009 di Jakarta. Ray Antylogic menekuni dunia sulap dari tahun 2006. Adapun pendidikan sulap yang pernah dijalani yaitu :

\section{IMS (International Magician Society)} pada tahun 2007 hingga 2008 di Jakarta.

2. Magic Castil pada tahun 2009 hingga 2010 di Bali.

Mulai pada tahun 2011 hingga saat ini Ray Antylogic terus mengembangkan Three Logic Academy and Community (3Logic) khususnya di wilayah Bandar Lampung dan sekitarnya. Untuk memperkuat data yang diperoleh, maka informan sekunder dalam penelitian ini adalah penonton pertunjukan sulap klasik. Adapun penentuan informan sekunder berdasarkan metode Snow Ball Sampling. Informan sekunder ditentukan dengan kriteria tertentu.

\section{DISKUSI TEMUAN}

Bahasa tubuh atau pesan kinesik adalah bagian dari komunikasi pesan non verbal (komunikasi tanpa kata-kata). Bahasa 
tubuh merupakan proses pertukaran ide, pikiran dan gagasan dimana pesan yang disampaikan dari komunikator kepada komunikan dapat berupa isyarat, ekspresi wajah, pandangan mata, sentuhan, artifak (lambang yang digunakan), diam dan suara serta postur tubuh. Ray L. Birdwhistell menjelaskan lebih lanjut bahwa pada setiap anggota tubuh seperti wajah (termasuk senyuman dan kontak mata), tangan, kepala, kaki, dan postur tubuh memiliki makna tersendiri. Adapun makna kinesik dalam pertunjukan sulap klasik "Ray Antylogic" tersebut, antara lain:Pesan Fasial. Ekspresi wajah merupakan suatu hal sangat menentukan pesan yang ingin disampaikan seseorang dengan menunjukkan ekspresi wajah tertentu. Wajah merupakan kekuatan saluran komunikasi non verbal yang diterjemahkan atau di-encode oleh pengirim kemudian di-decode oleh penerima dengan makna yang berlaku dalam suatu konteks sosial dan budaya tertentu. Adapun ekspresi wajah menurut Vijaya Kumar, digunakan untuk menguatkan pembicaraan atau menggantikan kata-kata. Berikut merupakan beberapa ekspresi wajah masyarakat dunia menurut Vijaya Kumariii:

\section{Tabel 1 Ekspresi Wajah}

\begin{tabular}{|c|c|c|c|c|c|}
\hline No & $\begin{array}{l}\text { Ekspresi } \\
\text { Wajah }\end{array}$ & $\begin{array}{l}\text { Mata dan } \\
\text { Alis }\end{array}$ & Pipi & Hidung & Mulut \\
\hline 1. & Bahagia & $\begin{array}{l}\text { Bagian bawah } \\
\text { kelopak mata } \\
\text { agak } \\
\text { terangkat, } \\
\text { terlihat ada } \\
\text { kerutan dan } \\
\text { mata } \\
\text { menyipit. }\end{array}$ & $\begin{array}{l}\text { Mem } \\
\text { erah } \\
\text { dan } \\
\text { mem } \\
\text { besar }\end{array}$ & & $\begin{array}{l}\text { Bibir } \\
\text { dan } \\
\text { mulut } \\
\text { meleba } \\
\text { r, } \\
\text { kadang } \\
- \\
\text { kadang } \\
\text { gigi } \\
\text { terlihat }\end{array}$ \\
\hline 2. & Sedih & $\begin{array}{l}\text { Ujung dalam } \\
\text { alis terangkat, } \\
\text { mata } \\
\text { berlinang air } \\
\text { mata. }\end{array}$ & & & $\begin{array}{l}\text { Sudut } \\
\text { mulut } \\
\text { tertarik } \\
\text { ke } \\
\text { bawah } \\
\text { dan } \\
\text { bibir } \\
\text { gemeta } \\
\text { r. }\end{array}$ \\
\hline 3. & Marah & $\begin{array}{l}\text { Alis ditarik ke } \\
\text { dalam, mata } \\
\text { menyipit. }\end{array}$ & & $\begin{array}{l}\text { Beberapa } \\
\text { orang } \\
\text { mengemb } \\
\text { angkan } \\
\text { hidung. }\end{array}$ & $\begin{array}{l}\text { Bibir } \\
\text { tertutu } \\
\text { p rapat. }\end{array}$ \\
\hline
\end{tabular}

Dalam pertunjukan sulap klasik yang ditampilkan oleh "Ray Antylogic" terdapat beberapa ekspresi wajah yang paling dominan, yaitu :

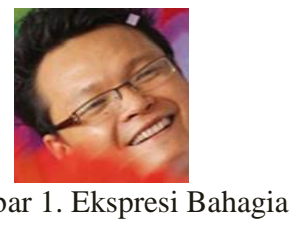

Gambar 1.adalah ekspresi bahagia yang dimiliki seseorang. Hal ini dapat dilihat atau diamati dengan ciri-ciri yang dapat dilihat: 
1. Bagian bawah kelopak mata agak terangkat, terlihat ada kerutan seperti jejak kaki gagak dan mata menyipit.

2. Pipi yang agak terangkat naik.

3. Bibir dan mulut melebar, yang kadangkadang gigi terlihat.

Ekspresi yang ditampilkan pesulap dalam pertunjukan sulap klasik berhasil sampai pada penonton. Maka dapat disimpulkan pesan kinesik yang ditampilkan pesulap melalui gerakan sulap dapat dimengerti dan dipahami oleh penonton dan dapat dikatakan bahwa terdapat kesamaan makna antara pesulap dan penonton. Selain ekspresi bahagia dalam pertunjukan

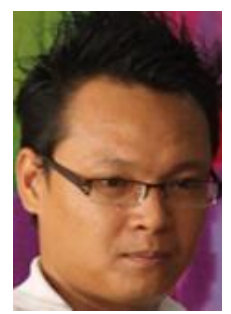

sulap klasik yang ditampilkan "Ray Antylogic" juga terdapat ekspresi terkejut seperti yang ada dalam gambar 2. Disini dapat terlihat ekspresi terkejut dengan ciriciri sebagai berikut :

Gambar 2. Ekspresi Terkejut

1. Alis mata naik.

2. Mata terbuka agak lebar.

3. Mulut terbuka.

Ekspresi terkejut ini biasanya terjadi hanya satu detik. Sehingga terkadang penangkapan oleh indra akan terlewatkan terkecuali ekspresi ini memang sengaja dibuat, akan ada beberapa point yang akan terlewatkan seperti apa yang ada dalam gambar 2. Dalam gambar tersebut point 2 yaitu mata terbuka agak lebar hal ini tidak didapatkan karena pada dasarnya sang pesulap dalam keadaan senang atau bahagia. Ekspresi yang ditampilkan pesulap dalam pertunjukan sulap klasik berhasil sampai pada penonton. Maka dapat disimpulkan pesan kinesik yang

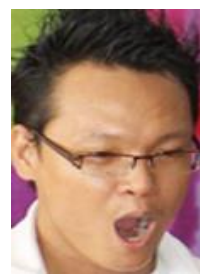

ditampilkan pesulap melalui gerakan sulap dapat dimengerti dan dipahami oleh penonton dan dapat dikatakan bahwa terdapat kesamaan makna antara pesulap dan penonton. Selanjutnya ekspresi dominan yang terdapat dalam pertunjukan sulap klasik yang ditampilkan "Ray Antylogic" yaitu ekspresi sedih dengan ciri-ciri sebagai berikut:

Gambar 3. Ekspresi Sedih

1. Ujung dalam alis terangkat.

2. Kelopak mata atas terkulai.

3. Mata berlinang air mata.

4. Mata kehilangan fokus.

5. Sudut mulut tertarik ke bawah dan bibir gemetar atau sisi-sisi bibir sedikit tertarik ke bawah.

Ekspresi yang diinginkan dan ditampilkan oleh pesulap dalam pertunjukan sulap klasik berhasil sampai pada penonton. Maka dapat disimpulkan pesan kinesik 
yang ditampilkan pesulap melalui gerakan sulap dapat dimengerti dan dipahami oleh penonton dan dapat dikatakan bahwa terdapat kesamaan makna antara pesulap dan penonton. Bagian wajah yang tidak dapat menyembunyikan emosi seseorang salah satunya adalah senyuman. Menurut Surmana, secara umum terdapat 3 bentuk senyuman $^{\text {xiii }}$ yaitu:

\section{Senyum Simpul}

Senyum simpul adalah bentuk senyuman yang tidak memperlihatkan gigi. Senyuman ini biasanya terjadi ketika seorang individu berada pada lingkungannya sendiri atau individu ini sedang sendirian. Individu tersebut tersenyum untuk dirinya sendiri.

\section{Senyum Biasa}

Senyum biasa adalah bentuk senyuman dengan memperlihatkan gigi seri bagian atas. Dalam senyum ini juga terjadi kontak mata antar individu, dapat dikatakan senyum ini merupakan salam saat bertemu antar individu dalam lingkungan kegiatan di luar individu.

\section{Senyum Lebar}

Senyum ini terjadi pada saat emosi individu berada pada taraf bahagia atau bergembira. Senyuman ini memperlihatkan gigi seri bagian atas dan bawah serta terjadi kontak mata dengan individu lain.
Dalam pertunjukan sulap klasik ini juga"Ray Antylogic" menampilkan ketiga ekspresi senyuman di wajah yaitu :
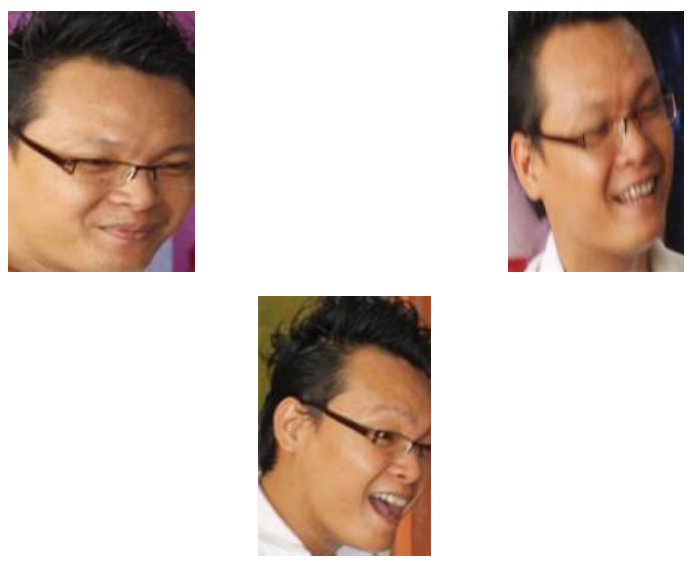

Gambar 4. Senyum Simpul

Gambar 5. Senyum Biasa

Gambar 6. Senyum Lebar

Ekspresi senyuman yang ditampilkan pesulap dalam pertunjukan sulap klasik berhasil sampai pada penonton. Maka dapat disimpulkan pesan kinesik yang ditampilkan pesulap melalui gerakan sulap dapat dimengerti dan dipahami oleh penonton dan dapat dikatakan bahwa terdapat kesamaan makna antara pesulap dan penonton. Setiap individu dilahirkan berbeda-beda, baik secara fisik maupun kepribadian. Wajah seseorang dapat mencermin sifat-sifat yang dimilikinya, mulai dari sifat sombong, ramah, hasrat seksual, kejujuran, ambisi, kreatifitas, kesehatan, ketekunan dan lain-lain. Beberapa bagian wajah yang dapat menerminkan kepribadian seseorang antara lain, bentuk wajah, hidung, dagu, telinga, alis, bibir dan mata. 
Kontak Mata atau Gerakan Mata. Titik pusat dari wajah individu adalah mata. Mata mengungkap sebagaian besar informasi, tempat kedua diduduki oleh ekspresi wajah. Setiap lebih banyak berkomunikasi dengan mata daripada dengan bagian lain dari anggota tubuh. Arah pandang kontak mata tidak pernah tetap. Arah pandangan mata juga mengkomunikasikan sesuatu. Pandangan tetap merupakan penatapan. Dalam banyak kebudayaan di dunia, penatapan merupakan hal yang tidak sopan. Penatapan mata pada manusia dapat juga menjadi tanda yang dominan dan mungkin berarti kesombongan. Dalam beberapa kebudayan lain mungkin terdapat perbedaan-perbedaan tatapan mata antara orang yang berbeda jenis kelamin, umur, kelompok, dan status yang berbeda merupakan parameter lainnya. Berikut ini adalah beberapa macam pergerakan mata $^{\text {xiv }}$ :

\section{Tabel 2. Pergerakan Mata}

\begin{tabular}{|c|c|c|}
\hline No. & Pergerakan Mata & Makna \\
\hline 1. & $\begin{array}{l}\text { Mata bergerak ke } \\
\text { kanan sekaligus ke } \\
\text { bawah. }\end{array}$ & $\begin{array}{l}\text { Sedang mencoba } \\
\text { mengakses perasaan. }\end{array}$ \\
\hline 2. & $\begin{array}{l}\text { Mata bergerak ke } \\
\text { kiri dan ke bawah. }\end{array}$ & $\begin{array}{l}\text { Sedang berbicara kepada } \\
\text { dirinya sendiri. }\end{array}$ \\
\hline 3. & $\begin{array}{l}\text { Mata bergerak ke } \\
\text { atas dan ke kiri. }\end{array}$ & $\begin{array}{l}\text { Sedang mencoba } \\
\text { membayangkan sesuatu } \\
\text { yang terjadi sebelumnya. }\end{array}$ \\
\hline 4. & $\begin{array}{l}\text { Mata bergerak ke } \\
\text { atas dan ke kanan. }\end{array}$ & $\begin{array}{l}\text { Sedang mencoba } \\
\text { membayangkan sesuatu. }\end{array}$ \\
\hline
\end{tabular}

\begin{tabular}{|c|c|c|}
\hline 5. & $\begin{array}{l}\text { Mata hanya } \\
\text { bergerak ke kiri }\end{array}$ & $\begin{array}{l}\text { Sedang mencoba untuk } \\
\text { mengingat suara. }\end{array}$ \\
\hline 6. & $\begin{array}{l}\text { Mata hanya } \\
\text { bergerak ke kanan }\end{array}$ & $\begin{array}{l}\text { Sedang mencoba untuk } \\
\text { merekontruksi suara. }\end{array}$ \\
\hline 7. & $\begin{array}{l}\text { Memutar mata ke } \\
\text { atas. }\end{array}$ & $\begin{array}{l}\text { Akan dianggap sebagai } \\
\text { suatu penghinaan secara } \\
\text { langsung kepada lawan } \\
\text { bicara, karena terkesan } \\
\text { tidak sabar dan jengkel. }\end{array}$ \\
\hline 8. & $\begin{array}{l}\text { Mata akan } \\
\text { membesar. }\end{array}$ & Heran atau kaget. \\
\hline 9. & $\begin{array}{l}\text { Gagap mata yaitu } \\
\text { ketika kedipan } \\
\text { mata seseorang } \\
\text { tidak teratur. }\end{array}$ & Kebingungan . \\
\hline
\end{tabular}

Dalam pertunjukan sulap klasik ini juga"Ray Antylogic" menampilkan beberapa kontak mata atau pergerakan mata di wajah "Ray Antylogic" yaitu :

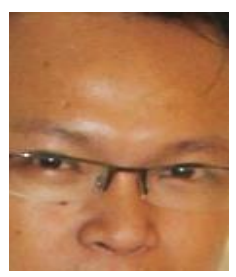

Gambar 7. Kontak mata atau pergerakan mata

Dalam gambar 7. dapat terlihat pergerakan mata hanya bergerak ke kanan hal ini dapat diartikan jika sang pesulap sedang mencoba untuk merekontruksi suara. Dalam pertunjukan sulap yang sedang berjalan pesulap harus dapat berpikir cepat apa yang akan selanjutnya ditampilkan bukan hanya peralatan namun juga suara atau kata-kata yang ditampilkan atau disampaikan dengan gerakan-gerakan tubuh atau kinesik. 
Gambar 8. Kontak mata atau pergerakan mata

Pada gambar 8. pergerakan mata ke atas dan ke kiri hal tersebut dapat diartikan sang pesulap sedang mencoba membayangkan sesuatu yang terjadi sebelumnya. Hal ini dapat menggambarkan bahwa pertujukan sulap klasik adalah satu kesatuan dari semua permainan sulap klasik dalam pertunjukan tersebut. Sang pesulap tidak hanya memikirkan bagaimana pesan kinesik tersebut disampaikan namun juga bagaimana kinesik itu sendiri dapat dimengerti dengan mudah oleh penonton. Memikirkan bagaimana reaksi penonton dalam permainan sebelumnya dapat menjadi acuan untuk permainan selanjutnya.

Gambar 9. Kontak mata atau pergerakan mata

Pergerakan mata ke kanan dan sekaligus ke bawah mengartikan sang pesulap sedang mencoba mengakses perasaan. Perasaan atau emosi adalah hal yang paling rawan dalam pertunjukan sulap. Hal ini dikarenakan dalam kinesik terkhususnya pada pesan fasial, perasaan atau emosi adalah yang paling cepat terungkap. Ada dampak positif dan negatif tersendiri mengenai hal ini. Dampak positifnya apabila apa yang ingin ditampilkan sesuai dengan perasaan atau emosi saat itu maka akan menambah nilai lebih dari pertunjukan tersebut namun, apabila berlawanan maka akan menjadi bumerang dalam pertunjukan sulap tersebut dapat juga menimbulkan kegagalan dalam pertunjukan sulap tersebut.

Pesan Gestural. Gesturmeliputi gerakan tangan saat berkomunikasi. Jika seseorang gagal dalam memberikan isyarat saat berbicara maka dapat dianggap membosankan, kaku dan tidak hidup. Gestural atau gerakan tangan sering kali disertai dengan ucapan atau perkataan. Demikian pula pada pertunjukan sulap klasik yang merupakan pertunjukan sulap yang minim dialog dan membutuhkan interpretasi yang mendalam terhadap gerakan-gerakan tubuh yang ditampilkan oleh pesulap. Dalam pertunjukan sulap klasik yang ditampilkan oleh "Ray

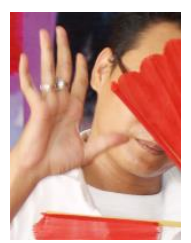

Antylogic" terdapat beberapa gerakan tangan atau pesan gestural, antara lain :

Gambar 10. Gerakan tangan

Gambar 10. sebuah gerakan yang tanpa disadari sering dilakukan. Bagi sebagian orang gerakan yang dilakukan adalah 
wajar namun sebenarnya gerakan tersebut memiliki arti bagi mereka yang berkebutuhan khusus. Seperti gerakan:

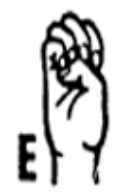

Gambar 11. Gerakan tangan yang berarti "E

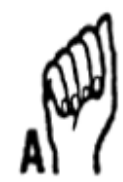

Gambar 12. Gerakan tangan yang berarti "A"

Dalam pertunjukan sulap, banyak sekali menampilkan gerakan tangan yang terbuka. Dalam pesan gestural, gerakan tangan terbuka ini dapat dimaknai atau dikaitkan kebenaran, kejujuran, kesetiaan dan rasa patuh. Telapak tangan terbuka juga dapat dimaknai berbeda dalam setiap kebudayaan seperti "kesini" dengan melambaikan telapak tangan yang terbuka untuk memanggil orang mendekat belainan dengan hal tersebut, di Indonesia, Pakistan atau Ghana melambaikan tangan dengan telapak tangan terbuka berarti“selamat tinggal”.

Pesan Postural. Pesan postural atau postur tubuh merupakan salah satu bentuk dari kinesik. Postur tubuh adalah adalah sikap tubuh atau bagian tubuh yang terjadi dalam durasi cukup lama (lebih dari 2 detik), sehingga bisa menjadi ekspresi sikap dan perasaan. Postur tubuh bersifat simbolik. Dari studi eksperimental yang dilakukan oleh James pada tahun 1932, terdapat 4 kategori postur tubuh ${ }^{\mathrm{xv}}$, sebagai berikut:

\section{Tabel 3 . Kategori pesan postural}

\begin{tabular}{|c|c|c|}
\hline No. & Postur Tubuh & Makna \\
\hline 1. & $\begin{array}{l}\text { Forward lean } \\
\text { (condong ke depan), }\end{array}$ & "penuh perhatian". \\
\hline 2. & $\begin{array}{l}\text { Drawing back } \\
\text { (menarik diri ke } \\
\text { belakang) atau } \\
\text { turning away (pergi } \\
\text { atau membalikkan } \\
\text { badan/kepala), }\end{array}$ & "negatif", "penolakan". \\
\hline 3. & $\begin{array}{l}\text { Expansion } \\
\text { (mengembangkan } \\
\text { tubuh/anggota tubuh), }\end{array}$ & "bangga","sombong". \\
\hline 4. & $\begin{array}{l}\text { Forward-leaning } \\
\text { trunk (tubuh condong } \\
\text { ke depan), bowed } \\
\text { head (kepala } \\
\text { menunduk), drooping } \\
\text { shoulders (bahu } \\
\text { terkulai), dan sunken } \\
\text { chest (dada menekuk), }\end{array}$ & $\begin{array}{l}\text { "depresi/tertekan","sedih", } \\
\text { "putus asa". }\end{array}$ \\
\hline
\end{tabular}

Dalam pertunjukan sulap klasik terdapat beberapa postur tubuh yang ditampilkan, diantaranya adalah :

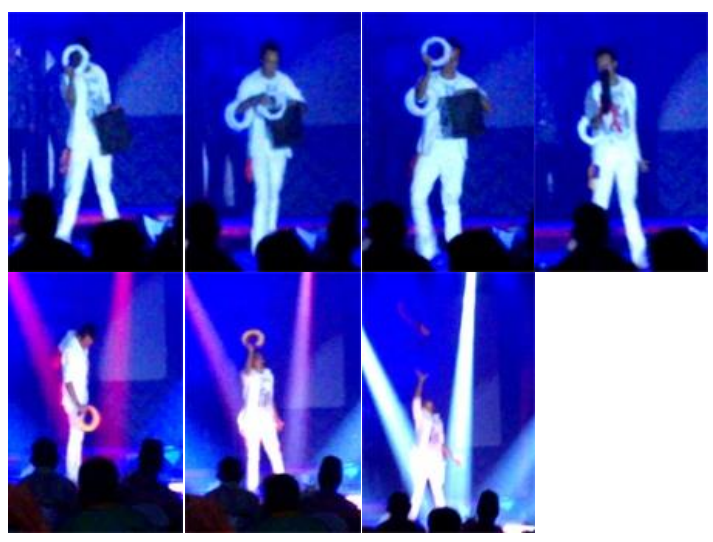

Gambar 14. Postur tubuh 
Berdasarkan gambar di atas, postur tubuh yang sering atau dominan ditampilkan oleh sang pesulap adalah postur tubuh tegap dan lebih cenderungExpansion (mengembangkan tubuh/anggota tubuh) yang dapat dimaknai sebagai kepercayaan diri tinggi, kebanggaan dan kesombongan. Namun, seseorang yang memilki karakteristik dan bentuk tubuh seperti yang ditunjukan sang pesulap sering dianggap sebagai seseorang yang memiliki jiwa kepemimpinan tinggi dan memiliki antusiasme tinggi.Postur tubuh yang ingin dan ditampilkan oleh pesulap dalam pertunjukan sulap klasik berhasil sampai pada penonton. Maka dapat disimpulkan pesan kinesik tersebut dapat dimengerti dan dipahami oleh penonton dan dapat dikatakan bahwa terdapat kesamaan makna antara pesulap dan penonton. Disini peneliti menguji bagaimana bentuk tubuh atau postur tubuh seseorang berkaitan dengan karakter atau kepribadian seseorang khususnya "Ray Antylogic", peneliti telah melakukan pendekatan secara individual dengan "Ray Antylogic" selama kurang lebih satu tahun, sehingga dapat dikatakan cukup untuk menjadi data dalam penelitian. Berikut ini adalah gambar atau foto "Ray Antylogic" :

Berdasarkan gambar atau foto di atas, "Ray Antylogic" masuk dalam kategori Mesomorph (atletis), hal ini dikarenakan "Ray Antylogic" memiliki tinggi 186 cm
Dengan berat badan $75 \mathrm{~kg}$ maka dapat dikatakan Mesomorph (atletis) dengan karakter atau kepribadian percaya diri, dewasa dan memiliki jiwa berpetualang. Well dan Siegel (1961) mesomorph juga digambarkan sebagai pribadi yang cerdas, bersahabat dan kompetitif.Postur tubuh atau pencitraan yang ingin dan ditampilkan oleh pesulap dalam pertunjukan sulap klasik berhasil sampai pada penonton. Maka dapat disimpulkan pesan kinesik tersebut dapat dimengerti dan dipahami oleh penonton dan dapat dikatakan bahwa terdapat kesamaan makna antara pesulap dan penonton.

\section{PENUTUP}

Dalam penelitian ini dapat disimpulkan bahwa seorang pesulap merangkai atau menyampaikan pesan kinesik kepada penonton saat pertunjukan sulap klasik. Pertunjukan sulap klasik merupakan pertunjukan sulap yang minim dialog dan membutuhkan interpretasi yang mendalam terhadap gerakan-gerakan tubuh yang ditampilkan oleh pesulap. Secara umum, pesan kinesik yang ditampilkan pesulap dapat dikatakan berhasil, yang mana pesan kinesik tersebut dapat dipahami dan dimengerti oleh penonton. Pesan kinesik terutama makna pesan gestural dan postural lebih dapat tangkap oleh penonton, Sedangkan makna pesan fasial yang tidak dapat dilakukan dengan sengaja yang hanya terjadi secara alamiah atau 
spontan. Perlu adanya peningkatan dalam pengendalian emosi atau perasaan dalam penampilan, sehingga dapat terlihat alami tanpa dibuat-buat.

Berkaitan dengan pesan fasial seperti raut wajah atau ekspresi wajah, terdapat kesamaan makna antara penonton dan pesulap. Ekspresi wajah yang ada dalam pertunjukan sulap klasik anatara lain: ekspresi wajah bahagia, ekspresi wajah sedih, dan ekspresi wajah terkejut. Kemudian dalam ekspresi wajah ini dapat ditemukan beberapa ekspresi tersenyum (senyum simpul, senyum biasa, dan senyum lebar).Kontak mata, dalam penelitian ini peneliti menemukan bahwa kontak mata atau gerakan mata tidak terlalu diperhatikan baik oleh pesulap ataupun penonton. Hal ini dapat dikarenakan gerakan mata terjadi dalam sekian detik sehingga terlalu sulit untuk diperhatikan dan pembelajaran mengenai gerakan mata tak didapat secara umum oleh masyarakat. Berdasarkan hasil penelitian, makna pesan kinesik fasial terkhusus pada ekspresi wajah dapat dipahami atau dimengerti oleh penonton. Gerakan tangan (Makna Pesan Gestural) dalam permainan sulap klasik lebih pada pengisyaratan mengenai sesuatu hal. Dapat dikatakan gerakan tangan menggantikan pesan verbal yang ingin disampaikan pesulap. Pada pertunjukan sulap klasik yang ditampilkan oleh pesulap, makna pesan gestural atau gerakan tangan dapat dimengerti dan dipahami dengan baik oleh penonton. Postur tubuh atau posisi tubuh lebih pada pencitraan diri seseorang. Bagaimana bersikap melalui pesan postural akan memberikan gambaran tehadap karakter diri yang ditujukan sebagai pencitraan diri pada orang lain, dalam hal ini pencitraan yang ditampilkan oleh pesulap secara baik tertangkap oleh penonton.

Kinesik memiliki peran yang sangat penting dalam kehidupan sehari-hari. Di bidang seni misalnya kecerdasan bahasa tubuh dapat diukur dari segi penghayatan seorang artis dalam bermain film, berteater, atau membaca puisi. Dalam bidang pendidikan, seorang guru akan menggunakan bahasa tubuh untuk memperjelas materi yang ia sampaikan.

\section{Endnote}

${ }^{1}$ Cangara, Hafied. 2006. Pengantar Ilmu Komunikasi. Jakarta: PT. Raja Grafindo Persada. Hlm.19-20

${ }^{2}$ Ibid, hlm.99

${ }^{3}$ Rakhamat, Jalaludin. 2004. Psikologi Komunikasi. Bandung: Remaja Rosdakarya. Hlm.287

${ }^{4}$ Loc.cit. hlm.287-289

${ }^{5}$ Cangara, Hafied. Op.cit. Hlm.101

${ }^{6}$ Rakhamat, Jalaludin. Op.cit. Hlm. 289

${ }^{7}$ Rakhamat, Jalaludin. Op.cit. Hlm. 290

${ }^{8}$ Mulyana, Deddy. 2012. Ilmu Komunikasi: Suatu Pengantar. Bandung: Remaja Rosdakarya.

${ }^{9}$ Rakhamat, Jalaludin. Op.cit. Hlm. 290

${ }^{10} \mathrm{Ibid}$

${ }^{11}$ Jatmika, Agung dan Leonel Jibran. 2012. Jurus Kilat Jago Sulap Kartu. Bekasi: Laskar Aksara. Hlm.3

${ }^{12} \mathrm{Http}: / /$ Repository.Unhas.Ac.Id/Handle/12345678 9/1719. Kamis, 17 Oktober 2013. Jam 20:51 WIB 
${ }^{13}$ Sumarna, S. Hardja. 2013. Tips Menaklukan Orang-Orang Disekitar Dengan Membaa Bahasa Tubuhnya. Klaten: Cable Book.

${ }^{14} \mathrm{Http}$ //Repository.Unhas.Ac.Id/Handle/12345678

9/1719. Kamis, 17 Oktober 2013. Jam 20:51 WIB

${ }^{15} \mathrm{Http}: / /$ Repository.Unhas.Ac.Id/Handle/123456789/171

9. Kamis, 17 Oktober 2013. Jam 20:51 WIB 

